\title{
PENERAPAN PROJECT-BASED LEARNING DENGAN STANDAR PROJECT MANAGEMENT BODY OF KNOWLEDGE
}

\author{
Ainun Jariyah \\ Program Studi Sistem Informasi Universitas Bina Nusantara Jakarta, Indonesia \\ E-mail: ainun.jariyah@binus.ac.id
}

Submission date: 2020-05-02

Accepted date: 2020-05-10

\begin{abstract}
The Republic of Indonesia has completed competency standards for tertiary institutions which will be approved and developed in the 21st century. The problem in this research is the use of monotonous student lecture methods that are less active in the learning process. This causes students to be passive, bored, lazy, and less enthusiastic in learning. An appropriate learning model is needed to enhance the expected learning where one of them is Project Based Learning (PBL). The purpose of this study is for students to understand the problem and develop critical thinking skills. PBL has been widely adopted and used in various fields because the learning model not only gives students knowledge, but also directs students to facilitate their understanding in real life relationships. Data collection methods are used to complete the library by updating and using two types of sources. The Project Based Learning learning model by studying the Project Management Agency (PMBOK) can improve learning outcomes, increase student activity, skills, knowledge, and abilities in accordance with 21 st century challenges.
\end{abstract}

Keywords: Learning, PBL, Students, PMBOK

\begin{abstract}
ABSTRAK
Republik Indonesia telah menyiapkan standar kompetensi untuk lulusan universitas untuk bertujuan melengkapi lulusan mereka dengan serangkaian keterampilan dan pengetahuan untuk bersaing di abad ke-21. Permasalahan pada penelitian ini adalah penggunaan metode ceramah yang monoton kurang merangsang keaktifan siswa dalam proses pembelajaran. Hal tersebut menyebabkan peserta didik menjadi pasif, bosan, malas, dan kurang bersemangat dalam belajar. Model pembelajaran yang tepat diperlukan untuk meningkatkan berbagai keterampilan yang diharapkan di mana salah satunya adalah Pembelajaran Berbasis Proyek (PBL). Tujuan dari penelitian ini agar siswa dapat mempelajari konsep pemecahan masalah dan mengembangkan kemampuan berpikir kritis. PBL telah banyak diadopsi dan digunakan dalam berbagai bidang karena model pembelajaran tidak hanya memberikan siswa pengetahuan, tetapi juga mengarahkan siswa untuk menerapkan pemahaman mereka dalam konteks kehidupan nyata. Metode pengumpulan data yang digunakan ialah tinjauan pustaka dengan melakukan serangkaian tahapan dan menggunakan dua jenis sumber. Hasil model pembelajaran Project Based Learning dengan pendekatan Project Management Body Of Knowledge () dapat meningkatkan hasil belajar, meningkatkan keaktifan siswa, keterampilan, pengetahuan, dan kemampuan yang sesuai dengan tantangan abad 21.
\end{abstract}

Kata Kunci: Pembelajaran , PBL, Siswa, PMBOK

\section{PENDAHULUAN}

Menjawab tantangan pendidikan abad 21, Pemerintah Republik Indonesia telah lama berusaha memenuhi standar kompetensi lulusan peserta didik yang mencakup sikap, pengetahuan, dan keterampilan. Kompetensi didefinisikan sebagai seperangkat sikap, pengetahuan, dan keterampilan yang harus dimiliki dan dikuasai oleh peserta didik setelah menyelesaikan pembelajaran.
Dalam Peraturan Pemerintah Republik Indonesia, secara umum diperlukan dua kompetensi untuk mencapai standar kompetensi lulusan yakni kompetensi dasar dan kompetensi inti. Kompetensi dasar didefinisikan sebagai kemampuan untuk mencapai kompetensi inti yang harus diperoleh peserta didik melalui pembelajaran. Sementara kompetensi inti adalah tingkat kemampuan untuk mencapai standar kompetensi lulusan yang harus dimiliki seorang peserta didik pada setiap tingkat kelas atau program 
(Peraturan Menteri Pendidikan Dan Kebudayaan No. 21, 2016)

Menurut (Slattery, 2006) menekankan pentingnya pendidikan yang berdasarkan pada konsep pendidikan yang mengimplementasikan visi 21 st century.

UNESCO telah membuat empat pilar pendidikan untuk menyongsong abad 21, yaitu (Singh, 1991):

1. Belajar untuk mengetahui (Learning to how)

2. Belajar untuk melakukan (Learning to do)

3. Belajar untuk mengaktualisasikan diri sebagai individu mandiri yang berkepribadian (Learning to be).

4. Belajar untuk hidup bersama (Learning to live together).

Permasalahan pada penelitian ini adalah penggunaan metode ceramah yang monoton kurang merangsang keaktifan peserta didik dalam proses pembelajaran. Hal tersebut menyebabkan peserta didik menjadi pasif, bosan, malas, dan kurang bersemangat dalam belajar. Model pembelajaran yang tepat diperlukan untuk meningkatkan berbagai keterampilan yang diharapkan di mana salah satunya adalah pembelajaran berbasis proyek (PBL). Tujuan dari penelitian ini agar siswa dapat mempelajari konsep pemecahan masalah dan mengembangkan kemampuan berpikir kritis.

Penelitian dari Muhammad Sopandi, Agus Efendi, Basori dengan judul Penerapan Model Pembelajaran Project Based Learning (PBL) Pada Mata Pelajaran Pemrograman Desktop Untuk Meningkatkan Hasil Belajar Peserta Didik Kelas Xi Rpl B Smk Negeri 2 Karanganyar. Penelitian ini adalah Penelitian Tindakan Kelas (PTK) yang dilakukan dalam dua siklus. Setiap siklus terdiri dari empat tahap: perencanaan, tindakan, pengamatan, dan refleksi. Subjek penelitian adalah siswa kelas 11 RPL B SMK Negeri 2 Karanganyar tahun ajaran 2015/2016, yang terdiri dari 38 siswa: 28 laki-laki dan 6 perempuan. Teknik pengumpulan data yang digunakan adalah dokumentasi, observasi, tes, dan wawancara. Validasi data dilakukan dengan menggunakan triangulasi dan analisis data dilakukan dengan menggunakan statistik komparatif deskriptif. Hasil penelitian menunjukkan bahwa penerapan model pembelajaran Project Based Learning (PBL) dalam mata pelajaran pemrograman desktop dapat meningkatkan hasil belajar siswa. Hasil penelitian menunjukkan peningkatan proporsi siswa yang berhasil lulus dari 33,33\% di pra-siklus, $40,00 \%$ di siklus I, dan 96,97\% di siklus II untuk domain kognitif; 3,03\% pada pra-siklus, 56,25\% pada siklus I, dan $84,85 \%$ pada siklus II untuk domain afektif; $0,00 \%$ pada pra-siklus, $40,63 \%$ pada siklus I, dan $81,82 \%$ pada siklus II untuk domain psikomotorik; dan $6,06 \%$ pada siklus awal, $50,00 \%$ pada siklus I, dan 93,94\% pada siklus II untuk aspek keaktifan (Muhammad Sopandi, Agus Efendi, 2017).

Penelitian dari Erni Murniarti dengan judul Penerapan Metode Project Based Learning Dalam Pembelajaran. Project Based Learning bertujuan untuk menemukan pemecahan masalah, disamping itu juga agar peserta didik mempelajari konsep cara pemecahan masalah dan mengembangkan kemampuan berpikir kritis. Dalam mempelajari konsep dan kemampuan berpikir kritis tersebut peserta didik bekerja secara bersama-sama dalam kelompoknya untuk mengkaji masalah-masalah riil. Pembelajaran dengan menerapkan metode pembelajaran ini diharapkan dapat membuat peserta didik menjadi lebih aktif dan kreatif, dengan belajar dari apa yang mereka lihat dari lingkungannya (Murniarti, 2017).

Pendidikan yang membangun "partnership $21^{\text {st }}$ century learning" merupakan sebuah kerangka berpikir pembelajaran abad 21 yang menuntut peserta didik memiliki keterampilan, pengetahuan, dan kemampuan di bidang teknologi, media dan informasi, keterampilan pembelajaran, inovasi, keterampilan hidup. Guna meningkatkan keterampilan yang diharapkan, dibutuhkan model pembelajaran yang sesuai. Project Based Learning (PBL) menjadi salah satu model pembelajaran yang dapat digunakan karena tidak hanya dapat membekali siswa dengan ilmu pengetahuan namun juga mengarahkan para peserta didik untuk mampu memahami dan mengimplementasikan pemahaman dalam konteks kehidupan nyata melalui cara kerja sama dalam kelompok. Setelah siswa terlibat secara langsung dalam PBL, diketahui terdapat peningkatan pada mahasiswa dalam penginternalisasian konsep dan keterampilan berhubungan dengan mata pelajaran (Stearns, 2008).

Selain itu, diketahui pula bahwa para mahasiswa memiliki kecenderungan untuk mengingat dan memahami berbagai informasi yang didapatkan melalui pelaksanaan PBL. Hal ini sesuai dengan kompetensi "partnership $21^{\text {st }}$ century learning" yang diusung oleh Hermawan, dimana di antaranya adalah quantum learning, cooperative learning, society technology science, dan accelerated learning (Hernawan, 2006)

Menurut (Thomas, 2000) menerangkan penyebab bagaimana mahasiswa dapat mengaplikasikan kemampuan dan konsep yang mereka peroleh dari proses pembelajaran secara langsung tidak dalam tataran teori saja. Sehingga 
diakui bahwa pembelajaran keterampilan dengan model PBL menghasilkan pembelajaran yang relevan dan bermakna. Dari penelitian-penelitian yang sudah ada menunjukkan kekuatan PBL dalam mendukung peningkatan keterampilan mahasiswa yang tidak terbatas pada pendalaman ilmu pengetahuan. Namun juga untuk dapat bekerja sama untuk memecahkan masalah, mengkomunikasikan ide, berpikir kritis, dan menciptakan karya kreatif.

Kebaruan yang disajikan dalam penelitian ini adalah pendekatan dengan menggunakan lima kelompok proses berurutan dari Project Management Body Of Knowledge (PMBOK) dalam konteks project based learning secara umum. Diketahui bahwa untuk dapat mencapai keberhasilan penerapan proyek, diperlukan adanya lima hal yang mencakup memilih proses yang sesuai hingga menyeimbangkan kendala.

\section{METODE PENELITIAN}

Metode pengumpulan data yang digunakan dalam penelitian ini ialah studi pustaka:

1. Menghimpun dokumen-dokumen yang diperlukan dalam melakukan penelitian mencakup buku, literatur, catatan, dan laporan terkait dengan masalah yang menjadi obyek penelitian.

2. Mempelajari dan menelaah dokumendokumen tersebut.

3. Mengumpulkan teori-teori relevan yang menunjang penelitian. Studi kepustakaan yang dilakukan meliputi dokumen tertulis maupun media elektronik.

Sebagai penelitian kepustakaan, maka terdapat dua macam sumber data yang dipaparkan:

1. Sumber primer

Sumber primer dalam penelitian ini adalah Project Management Body Of Knowledge (PMBOK) yang dijadikan sumber utama acuan peneltian.

2. Sumber sekunder

Sumber sekunder berupa buku, literatur, catatan, dan laporan pendukung dan pelengkap bagi sumber primer

Motode Model Project - based Learning diantaranya yaitu siswa dihadapkan pada permasalahan konkret, mencari solusi, dan mengerjakan projek dalam tim untuk mengatasi suatu permasalahan.

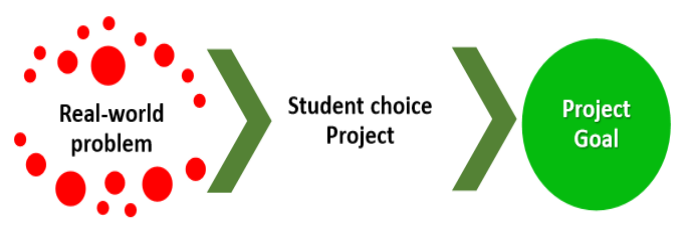

Sumber :(Hariant, 2018)

Gambar 1. Model Project Based Learning

Pada model Project - based Learning siswa tidak hanya memahami konten, tetapi juga menumbuhkan keterampilan pada peserta didik bagaimanan berperan di masyarakat. Keterampilan yang ditumbukan dalam PBL diantaranya keterampilan komunikasi dan presentasi, keterampilan manajemen organisasi dan waktu, keterampilan penelitian dan penyelidikan, keterampilan penilaian diri dan refleksi, partisipasi kelompok dan kepemimpinan, dan pemikiran kritis.

Penilian kinerja pada PBL dapat dilakukan secara individual dengan memperhitungkan kualitas produk yang dihasilkan, kedalaman pemahaman konten yang ditunjukkan, dan kontribusi yang diberikan pada proses realisasi proyek yang sedang berlangsung. PBL juga memungkinkan peserta didik untuk merefleksikan ide dan pendapat mereka sendiri, dan membuat keputusan yang mempengaruhi hasil proyek dan proses pembelajaran secara umum, dan mempresentasikan hasil akhir produk.

PMBOK merupakan standar praktik manajemen proyek yang disediakan oleh Project Management Institute, sebuah organisasi nonprofit global bergerak di bidang manajemen proyek. Standar yang diberikan mencakup identifikasi penggunaan alat, teknik, proses, dan pengunaan standar lain. Standar yang dikembangkan dan disepakati berdasarkan proses konsensus yang terdiri dari enam rangkaian tahapan yang sesuai dengan prosedur American National Standards Institute (ANSI).

\section{HASIL DAN PEMBAHASAN}

Berdasar Project Management Body of Knowledge Guide Fifth Edition, manajemen proyek menerapkan pengetahuan, keterampilan, alat, dan teknik untuk memenuhi kegiatan proyek untuk memenuhi persyaratan proyek yang dapat dicapai dengan lima kelompok proses manajemen proyek yakni: 
1. Initiating

2. Planning

3. Executing

4. Monitoring and controlling

5. Closing

Lima kelompok proses digambarkan di Figur 1 berikut ini.

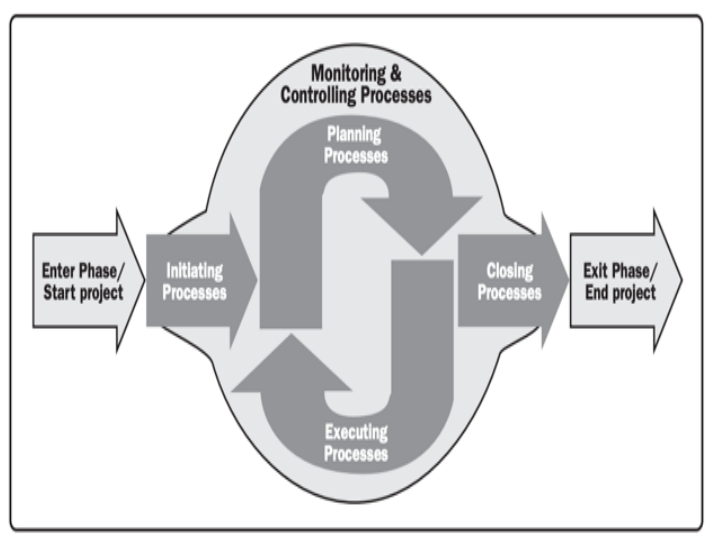

Sumber : (Ainun Jariyah, 2019)

Gambar 2. Kelompok proses manjemen Proyek

Kelompok proses iniating terdiri dari proses yang dilakukan untuk menentukan proyek baru atau fase baru dari sebuah proyek. Di kelompok proses ini, ruang lingkup awal dan sumber anggarakan didefinisikan. Begitu pun dengan pemangku kepentingan internal dan eksternal yang akan berinteraksi dan mempengaruhi hasil keseluruhan proyek. Seluruh informasi di dalam proses ini akan didokumentasikan dalam bentuk project charter dan stakeholder register.

Tujuan utama dari kelompok proses ini adalah untuk:

1. Menyelaraskan harapan pemangku kepentingan dengan tujuan proyek,

2. Memberi visibilitas tentang ruang lingkup dan tujuan,

3. Menunjukkan bagaimana partisipasi setiap pemangku kepentingan dalam proyek dan fase-fase terkait yang dapat memastikan ekspektasi mereka dapat dipenuhi.

Dalam implementasinya di dalam pembelajaran berbasis proyek, siswa akan bertemu dengan banyak pemangku kepentingan untuk membantu memperjelas kebutuhan dan kendala di proyek yang akan mereka jalankan. Serangkaian pertemuan akan diadakan untuk mempresentasikan situasi terbaru, mendengar gagasan para pemangku kepentingan, mengumpulkan feedback akan rencana yang diusulkan, dan menentukan tujuan dan hasil dari proyek.
Kelompok proses planning terdiri dari proses-proses untuk menetapkan ruang lingkup upaya, mendefinisikan dan memperbaiki tujuan proyek, dan mengembangkan tindakan yang diperlukan untuk mencapai tujuan tersebut. Hasil dari kelompok proses planning ini dalam bentuk project management plan dan project documents yang akan digunakan untuk melaknsanakan proyek. Sifat kompleks dari manajemen proyek memerlukan pengulangan feedback sebagai tambahan analisis. Semakin banyak informasi atau karakteristik dikumpulkan dan dipahami, perencanaan tambahan akan dibutuhkan. Manfaat utama dari kelompok proses planning ini adalah menggambarkan strategi dan taktik sebagai rangkaian jalur tindakan untuk menyelesaikan proyek dengan berhasil. Ketika planning berjalan dengan baik, keterlibatan pemangku kepentingan akan lebih mudah didapatkan.

Peserta didik atau siswa di fase kelompok proses planning ini akan mengklarifikasi peran masing-masing anggota proyek mereka. Setiap anggota proyek akan memiliki peran yang berbeda. Definisi peran ini mencakup kapan dan bagaimana setiap anggota akan berkontribusi pada proses. Seiring dengan proses planning, tenggat waktu dari setiap proses pengerjaan proyek dapat didefinisikan.

Kelompok proses executing terdiri dari proses yang dilakukan untuk menyelesaikan pekerjaan yang telah didefinisikan di dalam project management plan. Sebagai updaya untuk memenuhi spesifikasi proyek, kelompok proses ini melibatkan kordinasi antara anggota proyek dan sumber daya, mengatur ekspektasi pemangku kepentingan, serta mengintegrasikan dan melakukan aktifitas proyek sesuai dengan project management plan. Kelompok proses executing ini memerlukan pembaharuan perencanaan selama berlangsung yang meliputi perubahan durasi kegiatan, perubahan produktifitas dan ketersediaan sumber daya, dan risiko yang tidak terduga. Hal ini dapat memicu adanya change request yang apabila disetujui dapat mengubah project management plan dan project documents.

Peserta didik dalam kelompok proses ini akan menjalankan perannya masing-masing yang telah ditentukan. Untuk memudahkan pelacakan progress dari setiap anggota, milestone pun dibuat dan digunakan. Anggota proyek dapat mengadakan biweekly meetings untuk memberikan updates terkait dengan progress pekerjaan yang mereka kerjakan. Cara ini cukup efektif untuk memantau waktu yang dihabiskan dalam menyelesaikan satu aktifitas dan membuat penyesuaian yang kiranya diperlukan. 
Kelompok proses monitoring and controlling terdiri dari sekumpulan proses yang bertujuan untuk melacak, meninjau, dan mengatur progress dan performa proyek; mengidentifikasi area-area yang memerlukan perubahan; dan memulai perubahan yang sesuai. Manfaat utama dari kelompok proses ini adalah dapat mengukur dan menganalisis performa proyek secara berkala. Kelompok proses ini pun melibatkan pengontrolan perubahan dan rekomendais tindakan korektif atau preventif untuk mengantisipasi kemungkinan masalah dan memantau kegiatan proyek yang sedang berlangsung.

Pada kelompok proses monitoring and controlling ini, para peserta didik akan saling berkomunikasi dalam menjalankan perannya sebagai anggota proyek. Secara khusus, para anggota akan mengadakan pertemuan dengan para pemangku kepentingan untuk mengumpulkan wawasan dan mengembangkan pemahaman mereka akan kebutuhan proyek. Di kelompok proses ini akan para anggota proyek akan mengadakan kick-off meeting sebelum memulai proyek, biweekly meeting untuk memberikan update terkait proyek, dan pertemuan lainnya untuk memberikan fasilitasi peer-sharing dan pemecahan masalah. Sejumlah alat dan cara digunakan untuk mendukung setiap anggota proyek dalam pencapaian target yang ditetapkan bersama.

Kelompok proses closing terdiri dari sejumlah proses yang dilakukan untuk menutup aktifitas proyek dengan melakukan verifikasi terhadap proses-proses yang telah diselesaikan. Kelompok proses ini pun menutup proyek yang diselesaikan secara premature seperti:

1. Proyek yang dibatalkan

2. Proyek yang mengalami krises. Di situasi ketika kontrak tidak dapat ditutup secara formal, prosedur hand-over dapat diatur dan diselesaikan.

Di kelompok proses terakhir ini, para peserta didik sebagai anggota proyek dapat melakukan dokumentasi dari pelajaran yang diperoleh selama menjalankan proyek, mencatat dampak penyesuaian terhadap proses apapun, membuat arsip semua dokumen proyek yang relevan untuk nantinya digunakan sebagai data historis, menutup kegiatan pengadaan dan memastikan penghentiamn perjanjian yang berhubungan dengan proyek, dan melakukan penilaian terhadap anggota tim dan melepas sumber daya proyek.

Dalam penerapan di pembelajaran berbasis proyek, lima kelompok proses ini dapat dijadikan rujukan untuk mendukung keberhasilan proyek dengan tetap memperhatikan hal-hal berikut:

1. Memilih proses yang sesuai dengan pemenuhan tujuan proyek

2. Menggunakan pendekatan yang dapat disesuaikan untuk memenuhi persyaratan proyek

3. Membangun dan memelihara komunikasi dan keterlibatan yang tepat dengan para pemangku jabatan

4. Mematuhi persyaratan untuk memenuhi kebutuhan dan harapan pemangku kepentingan

5. Menyeimbangkan kendala antara ruang lingkup, jadwal, anggaran, kualitas, sumber daya, kualitas, dan resiko untuk dapat menghasilkan produk, layanan, dan hasil yang ditargetka

\section{KESIMPULAN}

Berdasarkan latar belakang diatas metode pembelajaran dengan model project-based learning dapat meningkatkan hasil belajar meningkatkan keaktifan siswa. Dan juga metode project-based learning dengan pendekatan Project Management Body Of Knowledge (PMBOK) dapat membantu peserta didik membangun keterampilan, pengetahuan, dan kemampuan yang sesuai dengan tantangan abad 21.

\section{DAFTAR PUSTAKA}

Ainun Jariyah. (2019). Penerapan Project-Based Learning Dengan Standar Project Management Body Of Knowledge.

Hariant, A. S. N. dan D. (2018). Model Pembelajaran Project Based Learning (PjBL). sibatik.kemdikbud.go.id

Hernawan, A. (2006). Pengembangan Kurikulum dan Pembelajaran. Departemen Pendidikan Nasional.

Muhammad Sopandi, Agus Efendi, B. (2017). Jurnal Ilmiah Pendidikan Teknik Kejuruan ( JIPTEK ). Jurnal Ilmiah Pendidikan Teknik Kejuruan, $X(2)$, https://jurnal.uns.ac.id/jptk.

Murniarti, E. (2017). Penerapan Metode Project Based Learning. Phyw, 3(2), 369-380.

Peraturan Menteri Pendidikan Dan Kebudayaan No. 21. (2016). Standar Isi Pendidikan Dasar Dan Menengah. www.kompasiana.com.

Singh, R. (1991). Education for Twenty-First Century. Asia Pacific Perspective. Presentation. 
Slattery, P. (2006). Curriculum Development in the Postmodern Era. Routledge.

Stearns, P. (2008). Project-Based Learning, 21st Century Skills and ISTE Standards. Beyond Testing.

Thomas, J. (2000). A Review Of Research On Project-Based Learning. http://www. bobpearlman.org/BestPractices/PBL_Resear ch.pdf 